\title{
Leading Donors' Approaches to SDGs Implementation ${ }^{1}$
}

\author{
A. Ignatov, S. Mikhnevich, I. Popova, E. Safonkina, A. Sakharov, A. Shelepov
}

Alexander Ignatov - Researcher, Centre for International Institutions Research, Russian Presidential Academy of National Economy and Public Administration; 20 Myasnitskaya Str., Moscow, 101000, Russian Federation; E-mail: ignatov-aa@ranepa.ru

Sergey Mikhnevich - PhD, Director of the Center for Multilateral Cooperation, Russian Union of Industrialists and Entrepreneurs; Researcher, Center for International Institutions Research, the Russian Presidential Academy of National Economy and Public Administration (RANEPA), 11 Prechistenskaya Naberezhnaya, Moscow, 119034, Russian Federation; E-mail: sxzex@yandex.ru

Irina Popova - Researcher, Centre for International Institutions Research, Russian Presidential Academy of National Economy and Public Administration; 20 Myasnitskaya Str., 101000, Moscow, Russian Federation; E-mail: impopva_1@ edu.hse.ru; popova-im@ranepa.ru

Elizaveta Safonkina - Researcher, Centre for International Institutions Research (CIIR), Russian Presidential Academy of National Economy and Public Administration (RANEPA); 11 Prechistenskaya naberezhnaya, 119034, Moscow, Russian Federation; E-mail: safonkina-ea@ranepa.ru

Andrei Sakharov - Researcher, Center for International Institutions Research, Russian Presidential Academy of National Economy and Public Administration; 11 Prechistenskaya naberezhnaya, 119034, Moscow, Russian Federation; E-mail: sakharov-ag@ranepa.ru

Andrey Shelepov - Researcher, Centre for International Institutions Research, Russian Presidential Academy of National Economy and Public Administration; 11 Prechistenskaya naberezhnaya, 119034, Moscow, Russian Federation; E-mail: shelepov-av@ranepa.ru

\section{Abstract}

The Sustainable Development Goals, adopted by the UN General Assembly on 25 September 2015, cover a wide range of challenges faced by developing and developed countries alike. The Agenda 2030 is focused on fighting poverty in all its manifestations through the implementation of strategies for sustainable economic growth.

The SDGs are relevant on both international and national levels. This article discusses the policy of the six major foreign aid donors in achieving the SDGs both domestically and abroad. The countries selected for the analysis include three major developed donors: Germany, Canada, and Japan, as well as three new developing donors: Brazil, India, and China.

The comparative analysis was based on such aspects of the national policy aimed at achieving the SDGs as: a) SDGs inclusion into national conceptual and strategic documents; b) institutional organization and social partners engagement; c) integration of the SDG priorities into foreign aid strategies; d) official ODA motivation; e) and the quality of communication policy on the SDGs implementation.

Based on a review of the aforementioned countries' experience in localizing the SDGs, the author makes recommendations to advance this agenda in the Russian Federation.

${ }^{1}$ The editorial board received the article in August 2018.

The research was carried out within the framework of the RANEPA research project "Leading Donors' Sustainable Development Goals Implementation Strategies.” 
Key words: Sustainable Development Goals; sustainable development; foreign aid; Agenda 2030; Official Development Aid

For citation: Ignatov A., Mikhnevich S., Popova I., Safonkina E., Sakharov A., Shelepov A. (2019) Leading Donors' Approaches to SDGs Implementation. International Organisations Research Journal, vol. 14, no 1, pp. 164-188 (in English). DOI: 10.17323/1996-7845-2019-01-10

The sustainable development agenda - commonly referred to as Agenda 2030 - adopted by the United Nations General Assembly (UN GA) on 25 September 2015 defined the primary direction for global development discourse, placing social, economic and environmental concerns at the fore of the future development agenda [UN, 2015]. The UN also pledged to "leave no one behind" [Stuart, Samman, 2017], committing to fight poverty, hunger and inequality by all means necessary. Agenda 2030 includes 17 sustainable development goals (SDGs) and 169 concrete targets encompassing a wide spectrum of global development issues, from facilitating inclusive economic growth to ensuring environmental sustainability and introducing more effective natural resources exploitation models.

Attaining the SDGs is central to both multilateral and national development agendas. The distinctive feature of the SDGs compared to the millennium development goals adopted in 2001 is their focus on the issues facing both developing and developed countries.

In terms of their content, the SDGs reflect the agendas of the key global governance institutions - the Group of 20 (G20) and the BRICS grouping of Brazil, Russia, India, China and South Africa - which are focused on ensuring strong, sustainable and balanced economic growth. They also reflect the national policy priorities of the Russian Federation, including those set out in the framework of the presidential decree "On National Goals and Strategic Objectives of the Russian Federation Through to 2024" [President of Russia, 2018].

In this regard, it seems appropriate to study the experience of the leading international assistance donors in the implementation of the SDGs at both national and international levels. The most important aspects in this context are the localization of the sustainable development goals in developing and developed countries and the modalities of SDG integration into national legislation, conceptual and strategic planning documents, as well as relevant government policies at federal and regional levels.

This article reviews the policies aimed at implementing the SDGs of the major international aid donors, both nationally and in the framework of their official development assistance (ODA) activities, and provides a comparative analysis thereof. Six countries - three major developed donors (Germany, Canada and Japan) and three emerging donors (Brazil, India and China) - were selected for the analysis. Based on the review of these countries' experiences localizing the SDGs, recommendations are provided for performing similar work in the Russian Federation. 
The results of the monitoring of the state policies on the areas touched upon in SDG 8 (decent work and economic growth) and SDG 12 (responsible consumption and production) conducted in the framework of the research project "Leading Development Assistance Donors' Strategies for Achieving the Sustainable Development Goals" by the Centre for International Institutions Research at the Russian Presidential Academy of National Economy and Public Administration (CIIR RANEPA) formed the basis of a comparative analysis on the following key aspects:

- inclusion of the SDG objectives into national conceptual and strategic documents and the balance between economic, social and environmental aspects of the SDGs in national sustainable development strategies or other official documents;

- institutional organization and inclusion of social partners (business, non-profit organizations, local communities, ethnic minorities, etc.);

- integration of SDG priorities into development assistance strategies;

- rationale for the selection of international assistance priorities; and

- the quality of communications policy regarding SDG implementation.

\section{The Inclusion of SDGs 8 and 12 into National Conceptual and Strategic Documents}

In most of the reviewed countries (Canada, Germany, Japan and India) national objectives and SDG implementation plans are consolidated within special documents designed specifically to meet the UN targets. Characteristic features of such documents are the adaptation of the goals to national circumstances, designation of executive bodies responsible for conducting concrete tasks and designation of specific targets with correspondent indicators and deadlines.

Germany's Sustainable Development Strategy was published in 2016 and updated in January 2017. The document reiterates Germany's commitment to sustainable development and sets the specific goals of the federal government with respect to each of the SDGs. The central element of the German strategy is the sustainable development management system based on concrete goals with deadlines for their implementation, indicators for continuous monitoring, a regulatory regime and the definition of the tasks for government bodies. The German authorities pledged to contribute to the achievement of all 17 sustainable development goals, both within the framework of national policy implementation and at the international level. Accordingly, the implementation processes of all 17 targets are considered to be closely interrelated. The adapted goals set out in the German sustainable development strategy and the corresponding objectives primarily concern the implementation of the SDGs at the national level [Federal Government of Germany, 2016a].

Similarly, Canada's Federal Sustainable Development Strategy, approved in 2016, is positioned as a "primary mechanism for planning and reporting on sustainable development" at the national level [Government of Canada, 2016]. An important element of the Canadian approach is the creation of a hierarchy of responsibility with relevant 
federal ministries and regional authorities having their specific targets. The federal strategy encompasses 26 government departments. The 2008 Federal Sustainable Development Act, which determines Canada's approach to sustainability, serves as a legislative basis for the federal sustainable development strategy. Sustainable development is understood as "development that meets the needs of the present without compromising the ability of future generations to meet their own needs." The basic principle of the Act is the premise that the basis of sustainable development is the effective use of natural, social and economic resources. Thus, it is vital that the decision-making process takes into account all of the aforementioned aspects of development [Government of Canada, 2008].

Developing countries also resorted to the creation of special tools aimed at achieving the SDGs. In India, the national development strategy (Collective Efforts, Inclusive Growth/"Sabka Saath Sabka Vikas") was spearheaded by Prime Minister Narendra Modi. To implement the strategy, the government of India adopted a three-year action plan for the financial years 2017-2018 and 2019-2020. At the same time, a 15-year vision is being implemented which includes a seven-year development strategy. All documents were prepared with the active participation of Indian state-level authorities.

Brazil has adopted a different approach to integrating the SDGs into national legislation and strategic documents. The country has not issued special documents on the implementation of the SDGs. The instrument that lays the foundations for sustainable development policies in Brazil is the 2015-2019 Multi-Year Plan. Multi-year plans, according to Brazil's constitution, are adopted every four years and define strategic goals and activities for the government, as well as outline a number of specialized programmes. The current plan includes 54 programmes and covers the whole range of issues of the country's socio-economic and political development.

Despite the fact that the current multi-year plan was drawn up without taking into account the SDGs (as it was developed before their adoption by the UN), it obviously touches upon many aspects of sustainable development. In its voluntary report to the UN High-Level Political Forum on Sustainable Development, Brazil notes that out of 169 SDG targets only 24 are not addressed in the plan in any way, while 145 tasks are to some extent covered by it. Out of 241 target indicators, 52 are not reflected in the plan, while 189 have a high degree of correlation with Brazilian national indicators [Presidency of the Republic of Brazil, 2017]. The 2016-2019 plan itself has 1132 target indicators distributed by thematic areas [Federal Government of Brazil, 2015]. The distribution of the various components of the plan (programmes, actions, initiatives and tasks) according to their relationship to the SDGs shows that most of the planned activities are aimed at achieving SDGs 2, 3, 8 and 16 [Presidency of the Republic of Brazil, 2017].

An important aspect of national sustainable development policy is the balance of social, economic and environmental objectives, as established by the SDGs. In general, governments are guided by their national circumstances and prioritize measures that address pressing issues of national development. One of the most notable examples in 
this regard is Canada's sustainable development strategy, focused primarily on addressing environmental sustainability issues and creating social and economic prerequisites for advancement in these areas.

The basis for effective work on integrating the SDGs into the general course of national socio-economic policy is the development of a specialized system of strategic documents that has a clear hierarchical structure and includes all relevant ministries and regional authorities in the implementation of the SDGs. Such an approach allows for the inclusion of both municipal organizations, having limited organizational and information and communications technology (ICT) capabilities, and non-governmental actors, including the business community, which can become one of the primary sources of investment for sustainable development.

\section{The Inclusion of Institutional Organization and Social Partners}

The distribution of responsibilities between state authorities and the involvement of non-state actors in the implementation of national sustainable development policies are significant factors in the localization of SDGs. The institutional structure of the executive bodies involved in conducting sustainable development policies reflects the national vision of the SDGs and the priority nature of certain industries.

In all of the countries analyzed, sustainable development strategies are comprehensive in nature and involve all or most government agencies. Special coordinating bodies are being created to ensure the coherence of government actions in the field of sustainable development. At the same time, along with coordinating the activities of state bodies, specific attention should be given to safeguarding the rights and interests of non-state actors such as civil society, business, and certain social and ethnic groups. In this regard the countries selected for analysis also demonstrate at least an institutional capacity to take into account the interests of these groups.

The tasks of monitoring the implementation of Germany's sustainable development strategy and of updating its content are entrusted to the State Secretaries' Committee for Sustainable Development, which includes the representatives of all federal ministries. The committee provides strategic input to the work of the German government and acts as a platform for various departments to exchange information on their activities in the field of sustainable development. The Parliamentary Consultative Council on Sustainable Development, in turn, supervises the implementation of the strategy, holds discussions on sustainable development issues in the German Parliament, and is also responsible for assessing the regulatory impact of federal government decisions in this area.

Additionally, the German government cooperates with the Sustainable Development Council, an independent advisory group that has supported the federal authorities since 2001, promoting social dialogue on sustainability. It consists of 15 public figures who, by virtue of their professional and personal experience, are well acquainted 
with the economic, environmental and social aspects of sustainable development in its national and international dimensions.

In Canada, the creation of a special body to coordinate national sustainable development policies was provided for under the 2008 Sustainable Development Act [Government of Canada, 2008]. The Sustainable Development Advisory Council, chaired by the minister of the environment, includes one representative from each province or territory, as well as three representatives each from aboriginal peoples, environmental non-governmental organizations, business associations and trade unions. Thus, the council serves to ensure both the consistency of the national sustainable development policies at all levels of government and the inclusion of non-state actors into decisionmaking processes.

Japan's work on the implementation of the SDGs at both national and international levels formally involves the entire government. The SDG Promotion Office, headed by the prime minister of Japan, was created to monitor and coordinate the efforts of state agencies. The membership of the office includes all the current ministers. In addition to coordinating and monitoring the activities of state bodies in the field of sustainable development, the office interacts with the representatives of business, NGOs, academia and regional authorities both in Japan and abroad.

Taking into account the interests of the social partners is the predominant trend in the work of public authorities in the context of adapting the SDGs to national development priorities. As noted above, the involvement of non-state actors in the process of developing, adopting and executing decisions can be a significant mechanism for organizing, promoting and financing activities in the field of sustainable development.

\section{Integration of SDGs into International Development Assistance Strategies}

As the SDGs are characterized by the universality of the issues they aim to tackle, the goals have both national and international dimensions. Table 1 shows the data on the official development assistance (ODA) of the countries analyzed in this paper.

Table 1. Volumes of Official Development Assistance from Germany, Canada, Japan, Brazil, India and China ( $\$$ billions)

\begin{tabular}{|l|c|}
\hline \multicolumn{1}{|c|}{ Country } & ODA Volume \\
\hline Germany & $24.7(2016)$ \\
\hline Canada & $4.34(2016)$ \\
\hline Japan & $10.41(2016)$ \\
\hline Brazil & $0.396(2013)$ \\
\hline India & $1.77(2015)$ \\
\hline China & $3.08(2016)$ \\
\hline
\end{tabular}


The most important question for donor countries in this context is the extent to which the integration of sustainable development objectives into their development assistance activities in other countries is possible. The reviewed countries respond to this question differently.

Germany regards all activities in the area of international development assistance as aimed at achieving the SDGs, in view of their comprehensive nature. Germany's aid aims to assist developing countries in enacting economic policy measures that ensure the greatest possible degree of economic prosperity, social equality and environmental protection, which form the foundation of a sustainable growth model. Along with state bodies' capacity building, which creates stable and equitable conditions for development, Germany regards private sector empowerment and support for micro, small and medium enterprises as cornerstones for sustainable economic growth in partner countries.

Canada ensures the integration of sustainable development priorities in its international aid activities in accordance with its own approach to the definition of sustainable development. Canada regards promoting sustainable development as the central element of the country's international assistance efforts. According to data from the Organisation for Economic Co-operation and Development (OECD), 29.5\% of Canada's ODA in 2014 was aimed at tackling environmental issues, while $4.5 \%$ was directed at combating climate change. Considerable attention is paid to another important topic covered by the SDGs - gender equality. According to OECD estimates, $60.2 \%$ of Canadian bilateral assistance was to some extent related to ensuring economic and social equality for women [OECD, DAC, 2016]. Assisting feminist organizations is another priority of Canada's international assistance. The department of international affairs directly links its policy in this area with the implementation of SDG 5 (achieve gender equality and empower all women and girls), however, it also contains the elements of SDG 8 (promote sustained, inclusive and sustainable economic growth, full and productive). Thus, the Feminist International Assistance Policy promoted by the Canadian government includes specific actions on women's economic rights and employment [Government of Canada, 2017].

Japan's specific measures to assist in the implementation of the SDGs at the international level are highly dependent on the specific situation of the recipient country. In its international assistance aimed at achieving the SDGs, Japan declares the priority to be human security, broadly defined to include healthcare development, reducing the risk of natural disasters and gender equality. Nevertheless, an analysis of examples of the practical implementation of Japan's priorities in the field of international assistance shows that social development is pursued in close conjunction with the promotion of economic reforms. Japan mostly provides assistance on SDG issues through the provision of development grants, which are the main international aid instruments employed by Japan.

The Chinese approach to the implementation of SDG policy is characterized by the complementarity of internal and external dimensions: the Chinese leadership con- 
siders the tasks of national and international development in conjunction. Many of the national practices (demonstration zones, business organization and financing formats, production technology and management) are then used internationally with certain adaptations to the conditions of the target countries and regions. The One Belt One Road initiative forms the framework for China's efforts in the area of SDG implementation. The priority sectors for international aid include development and modernization of the means of production, introduction of mass innovations, integrated industrialization, development of affordable financial services, digitalization and platformization of production, the provision of public services, infrastructure development, countering climate change and environmental degradation, training skilled workers and the creation of high-performance jobs.

\section{Rationale for the Selection of International Assistance Priorities}

International development assistance is inevitably associated with achieving certain national political priorities and ambitions. It is the relationship between the declared national development goals and the selection of priority areas for international assistance in the field of sustainable development which is of interest in this regard.

When considering the reasoning behind the national policies to promote SDGs at the international level, two main approaches were identified. The first is a declaration of practical interest in the development of other states. Factors of such interest may include development of bilateral trade with the recipient country, reduction of migration pressure from the recipient country and the strengthening of regional and global security. All of the countries reviewed adhere to this position except Canada.

According to the statements of the Federal Ministry for Economic Cooperation and Development of Germany, the choice of country and sectoral priorities for SDG activities is determined by several factors, one of which is a sharp increase in the number of migrants arriving from said country. In order to combat this challenge, efforts are being made to improve living conditions in the countries from which the majority of migrants, including, for example, Turkey, arrive to Germany. The measures are aimed at improving the quality of education, providing access to basic services and creating jobs. Another factor is economic interest. Given the development of global value chains, the success of German internationalized businesses is directly dependent on the economic situation in the countries of their presence. A third factor is the global problem of climate change, necessitating collective efforts by both developed and developing countries. Finally, another factor relates to the political commitments made by Germany within the framework of international institutions.

The constitution and the national security strategy of Japan define homeland security as the main factor for the country's involvement in development assistance efforts. Japan considers increasing the quality of life and promoting social and economic development of low-income countries as a guarantee of national security, with a sig- 
nificant part of long-term development programmes being primarily focused on accelerating economic growth.

Brazil's priority SDG areas, both domestically and internationally include: decent employment and job creation, the fight against youth unemployment, sustainable and efficient use of resources (primarily water and fossil fuels) and the development of tourism. Also, much attention is paid to the eradication of poverty, the fight against hunger and the development of infrastructure. In choosing partners for international development cooperation Brazil is primarily driven by the three considerations: the need to ensure security and economic development of its immediate neighbourhood, support for the economic growth of developing countries in order to turn them into potential trading partners and the promotion of the Portuguese language. These factors determine the main groups of the recipients: Latin American neighbours, African countries and members of the Community of Portuguese Language Countries.

The Chinese approach can be singled out as the clearest example of pragmatism in international assistance. The principles of mutual benefit, non-interference and nonconditionality are at the core of the Chinese international cooperation ideology. This increases the attractiveness of cooperation with the PRC to many developing countries that do not meet the conditions imposed by Western partners. In this context, China itself also has the opportunity to maximize the economic benefits of cooperation, since the interaction is reciprocal.

China's involvement in international efforts to promote SDGs in developing countries is driven by the desire to:

- develop under-developed western regions of China, as well as to create conditions for incremental development of the entire country's economy;

- create "China-oriented" international value chains and transfer less efficient industries abroad;

- generate demand for Chinese business services and utilize domestic capacity in order to ensure medium-high growth rates;

- form a diversified network of routes and conditions for the uninterrupted supply of resources to China and the transportation of Chinese goods to main export markets;

- strengthen national security by improving relations with partner states and by expanding the choice of economic foreign policy instruments; and

- promote China's "soft power" and form a platform for the country's international leadership through a set of institutions and projects.

Along with domestic socio-economic implications, China's implementation of the SDGs at home and abroad is perceived as the most important mechanism for strengthening its own international influence and creating the conditions for China's establishment as a legitimate global centre of power.

Canada embodies the opposite approach to identifying priority areas for international cooperation, including within the framework of SDG implementation. The main motives of Canada's activities in the field of international development assistance, in 
addition to prestige considerations, are the promotion of democratic principles and liberal values, including gender equality, and the integration of sustainable development priorities into recipient countries' economic policies, mainly in the context of climate change adaptation and mitigation. Another important goal of Canadian sustainable development policy is to spread awareness of sustainable development issues and the government's priorities and actions among the general population and civil society organizations both in Canada and in recipient countries.

Canada's international development efforts are carried out by Global Affairs Canada in accordance with regularly updated priorities. One of the goals set for 2017-2018 was to "increase the contribution of Canada to building a more equitable, inclusive and sustainable world." The primary targets in this area were to implement a new Canadian vision promoting dignity and improving the quality of life of the poorest and most vulnerable people, strengthening the economic well-being of women and girls based on Canada's competitive advantages, and making a significant contribution to the implementation of the sustainable development goals [Government of Canada, c. a., a].

\section{Quality of Communications Policy}

Another important component of international assistance policy, including in the context of achieving the SDGs, is maintaining a high-quality communications policy. Ensuring the availability, openness and transparency of information on government priorities, goals and specific measures in the field of sustainable development both domestically and abroad is an integral part of any donor state's foreign policy. In essence, disseminating information on the country's international assistance efforts and achievements among the largest possible number of actors can be considered one of the primary goals of the country's foreign aid policy as a whole.

The quality of communications policy encompasses not only the modalities of providing information on a country's foreign aid activities to the general public, but also transparency of decision-making mechanisms, as well as the use of international tools such as global governance institutions or the UN High-Level Political Forum on Sustainable Development, in order to promote a national vision of the SDGs.

It should be noted that developed countries are currently far ahead of their developing counterparts in terms of the availability and transparency of information provided by state authorities, in part due to the existing legislative mechanisms ensuring a high level of openness of information and inclusiveness of decision-making processes.

For example, in Canada, pursuant to the 2008 Official Development Assistance Accountability Act, Global Affairs Canada ensures the transparency and availability of data on funding and the nature of ongoing foreign assistance projects. All relevant information is available on a website hosted by the department [Government of Canada, c. a., b]. In July 2018, Canada's voluntary report to the UN High-Level Political Forum on Sustainable Development was published [Government of Canada, 2018]. The report was prepared by Global Affairs Canada, with input from a wide range of stakeholders 
including individual citizens, collected through an open survey on their contribution to the country's efforts in promoting sustainable development at the national and international levels. Before 2030, Canada plans to submit at least two voluntary reports on the implementation of the SDGs. In addition, it was announced that a new strategy for achieving the goals was being developed [Government of Canada, 2018].

In Germany, a sustainable development communication strategy was adopted in 2014. The press service of the federal government is allotted primary responsibility for the implementation of the strategy [Federal Government of Germany, c. a.] which provides for the regular publication of brochures and newsletters on the implementation of Germany's sustainable development strategy [Federal Government of Germany, 2014], and organizes conferences to discuss new revisions of the strategy at the federal and regional levels. The purpose of these activities, which also include publishing the Sustainable Development Strategy in German and English and a summary in all official UN languages, preparation of a newsletter on sustainable development, and maintenance of continuous dialogue with social partners, is to further raise general public and stakeholder awareness of the importance of sustainable development and the federal government's efforts to promote it. Constant, open and transparent exchange of information is considered a necessary condition for cooperation between the government and social partners in the framework of Germany's multilateral approach to the implementation of Agenda 2030 [Federal Government of Germany, 2018].

Germany's voluntary report to the UN High-Level Political Forum on Sustainable Development was published on 12 July 2016 [Federal Republic of Germany, 2016b]. The government drew from the UN's handbook and the relevant guidelines for the preparation of voluntary reviews, actively engaging with non-governmental actors in the preparation of its report [UN, 2019]. The text of the report was discussed with representatives of non-governmental organizations, local authorities, the academic community, business associations and trade unions in the framework of the Agenda 2030 dialogue forum.

Developing donors, despite the absence of established regulatory frameworks and practical expertise in the organization of communication processes on the SDGs and international assistance issues, demonstrate moderate progress in this area.

In contrast with many developing countries, India pursues a transparent policy regarding SDG implementation. The National Institution for Transforming India (NITI Aayog), the agency responsible for coordination and monitoring of SDG implementation in India, maintains a website with all the relevant information, including a description of the goals, India's voluntary report to the UN High-Level Political Forum on Sustainable Development, data on the correlation between the SDGs and the national development goals, expert assessments and advisory opinions, and progress reports from states on SDG implementation. The websites of ministries and departments involved in the implementation of the SDGs also provide information on programmes, annual reports and financial statements, and newsletters on government activities. All information is updated several times a month. 
NITI Aayog presented the first voluntary national report to the UN High-Level Political Forum on Sustainable Development on 19 July 2017. The report opens with a brief summary describing the national objectives and accomplishments on SDGs 1, 2, 3, 5, 9, 14 and 17. Each section of the report is dedicated to a specific SDG and includes statistical indicators as well as a description of the state programmes that relate to the SDG in question. In general, the report serves to highlight the positive role of the Modi Government in the formation of an inclusive society of universal well-being in India. The report portrays India as an ancient civilization with SDG principles firmly rooted in its historical foundations, including the rational use of natural resources and respect for the environment.

In Brazil, the question of developing and adopting a solid SDG communication strategy was raised by a commission on achieving the SDGs in February 2018. While it is too early to speak of the existence of a coherent strategy at this point, since the adoption of Agenda 2030, various digital platforms have been created in Brazil to inform the public and stakeholder groups of the SDGs, their significance for socio-economic development and possible ways to contribute.

Two basic principles form the basis of China's communication strategy in the field of achieving the SDGs: "mutual benefit" and "non-interference in internal affairs," closely associated with non-conditionality of aid, which is intrinsic to China's international assistance policy. At the international level, these principles are promoted through the implementation of large-scale projects, such as the One Belt One Road initiative. A distinctive feature of the Chinese communication strategy is that it targets both domestic and external actors. This approach is designed to showcase China's international prowess within the country, in accordance with the course towards the revival of "national spirit" and the growth of Chinese influence abroad. Government documents emphasize the mutually beneficial nature of the Chinese international aid [People's Republic of China, 2018]. This approach aims to reduce potential social tensions that could potentially arise from the fact that China directs significant resources to assist foreign nations despite the large number of unresolved socio-economic issues at home. At the same time, China actively uses the platforms of international organizations and informal multilateral institutions to promote its own international development assistance initiatives.

\section{Conclusion}

Most of the reviewed countries (Canada, Germany, Japan and India) have developed documents devoted specifically to the implementation of the SDGs. Characteristic features of such documents include the adaptation of the goals to national circumstances, designation of executive bodies responsible for conducting concrete tasks, and designation of specific targets with corresponding indicators and deadlines. For example, Canada adopted the Federal Sustainable Development Strategy, with the corresponding 26 departmental strategies. Similarly, the Japanese guidelines for the implementa- 
tion of the SDGs are designed to include measures to achieve the goals at the national and international levels.

A different approach to SDG implementation is the inclusion of measures to achieve the goals via existing national mechanisms, such as strategies for socio-economic development. Brazil's Multi-Year Plan 2016-2019, adopted in 2015, defines strategic and tactical goals and activities and includes 54 specialized programmes reflecting 145 of the 169 SDG targets.

From the point of view of the mechanisms used to promote sustainable development at the international level, developed countries predominantly resort to bilateral instruments (grants, technical assistance programmes, capacity-building, educational programmes, etc.). Thus, bilateral assistance amounts to more than $80 \%$ of ODA for Germany, $71 \%$ for Canada and $68 \%$ for Japan. These countries rely heavily on grant instruments and direct budgetary support measures aimed at promoting sustainable development in recipient countries to ensure that SDG priorities are effectively integrated into their national plans and programmes for economic growth.

Large developing donors are currently in the process of building up their own international development assistance capabilities, and therefore are making greater use of multilateral mechanisms. However, new donors are increasingly using bilateral cooperation mechanisms as well. In particular, Brazil, prioritizing South-South cooperation channels, is implementing bilateral programmes of technical assistance and advanced training in such areas as agriculture, healthcare, education and environmental protection. China, in turn, is actively expanding bilateral cooperation with recipient countries in the context of the implementation of the comprehensive One Belt One Road initiative.

An important factor shaping the donor countries' SDG implementation strategies at the international level is the rationale behind the choice of priority areas and partner countries. In addition to the obvious prestige advantages, donors pursue their specific pragmatic agendas. International aid is used, among other things, as a tool for promoting economic and trade interests, ensuring security, implementing political priorities (promoting the principles of democratic governance or supporting loyal regimes), alleviating social tensions in migration centres and reducing the anthropogenic environmental impact on a global scale. In addition, at least officially, objectives of a more humanitarian nature are indicated. This approach is characteristic of developed Western countries such as Canada, which has declared priorities for gender equality and the development of civil society in recipient countries at core of its foreign aid strategy.

In general, the reviewed countries demonstrate a sufficient balance between the economic, social and environmental aspects of the SDGs within the framework of their national sustainable development policies. Nevertheless, given the institutional structure of the responsible government bodies and the content of specific national sustainable development strategies, the prioritization of certain issue areas becomes apparent. Canada is a prime example in this regard, where, despite the comprehensive nature of its sustainable development strategy, most of its priorities and objectives are related to 
ensuring environmental sustainability. Social and economic goals often either play an auxiliary role to environmental ones or relate to specific ethnic groups and territories.

The governments' communication strategies can also play significant role in implementing the SDGs. Ensuring the availability, openness and transparency of information on government priorities, objectives and specific measures in the field of sustainable development both at the national level and abroad is an integral part of ensuring a policy's overall efficiency. In this regard, developed countries are far ahead of the developing ones, especially given that developing countries often lack universally accessible and regularly updated information portals containing relevant and comprehensive information on foreign aid and SDG implementation. Table 2 shows the information on the main indicators of the SDG integration into national policies and mechanisms of international assistance.

Based on this study of the leading donors' experiences localizing the SDGs, recommendations for the Russian Federation were developed on each of the five criteria considered in the article. The analysis demonstrates the importance of a systemic approach to the integration of the SDGs into national policy instruments. The most effective approach would include:

- adaptation of the SDGs to national conditions and development requirements;

- formation of a comprehensive conceptual and legislative framework for state authorities involved in SDG implementation, directly aimed at the fulfillment of the adapted goals;

- creation of a clear and transparent institutional structure of the responsible executive authorities at the federal and regional levels;

- creation of a conceptual framework for the interaction of government bodies and the delegation of authority from the federal levels to regions and municipalities (it is necessary to adopt a comprehensive strategy for sustainable development, including both national priorities and sectoral objectives); and

- ensuring the transparency of the decision-making and implementation processes.

Currently, despite the fact that a large number of SDG targets correspond to the priorities, outlined in Russian conceptual documents, in particular, the state programmes and the presidential decree "On National Goals and Strategic Objectives of the Russian Federation Through to 2024," there is no systematic approach to ensure a balance of the social, economic and environmental aspects of sustainable development. Moreover, there are no attempts to create comprehensive legislative and institutional structures necessary for developing officials' awareness of the SDGs, increasing their competence on the sustainable development issues, ensuring accountability and, ultimately, the planned implementation of the set objectives.

An important factor in terms of enhancing transparency and accountability of the decision-making process for creating sustainable development strategies and the implementation thereof is to ensure that the interests of the social partners (business, non-profit organizations, local communities, ethnic groups) are taken into account. 


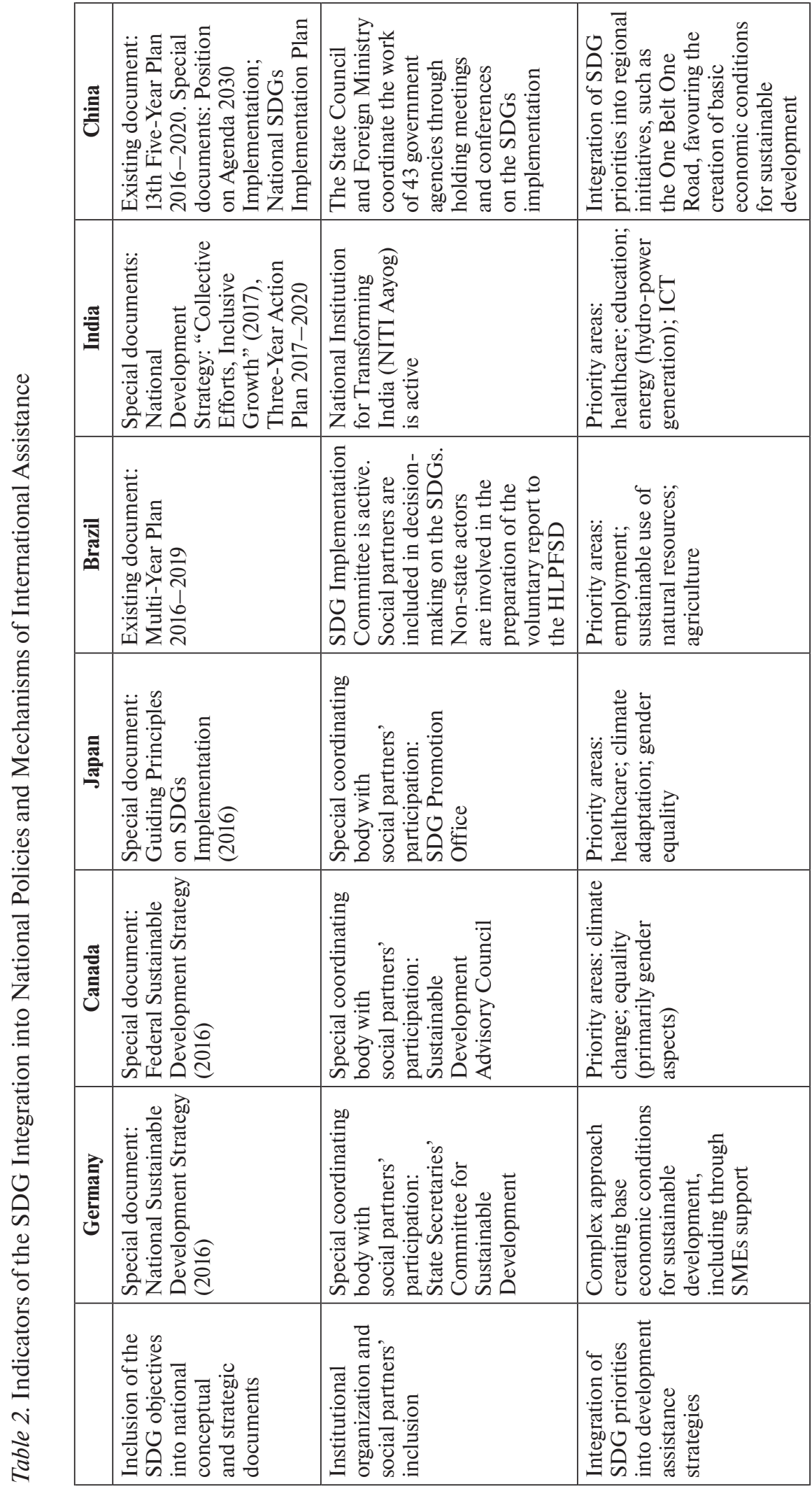




\begin{tabular}{|c|c|c|}
\hline 㞼 & 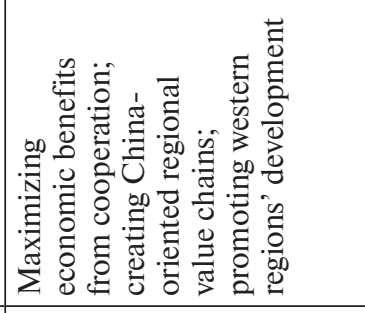 & 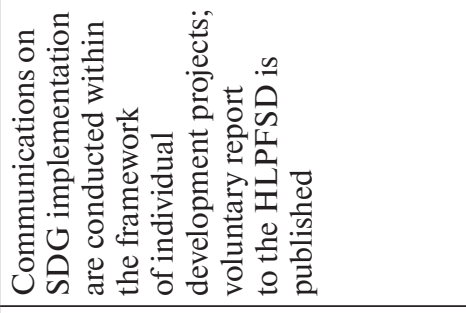 \\
\hline 嵒 & 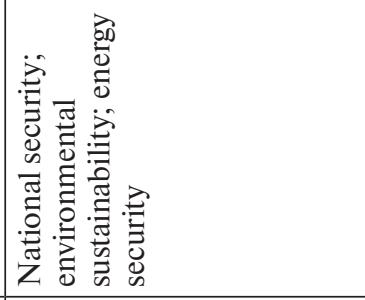 & 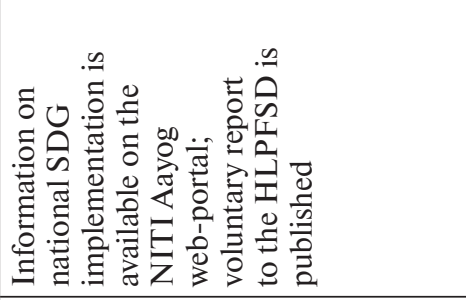 \\
\hline 包 & 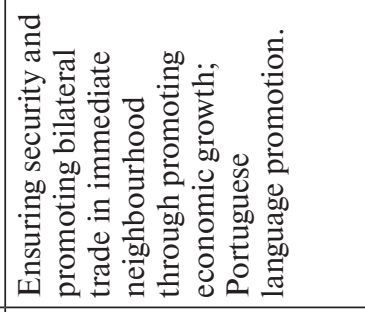 & 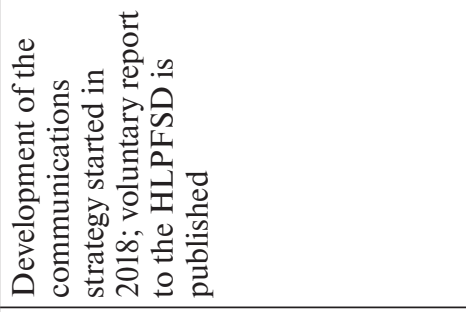 \\
\hline 壳 & 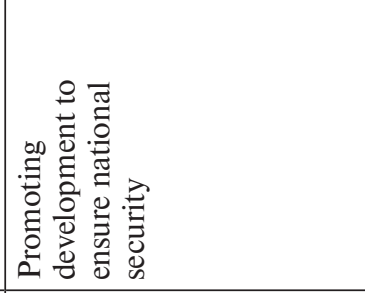 & 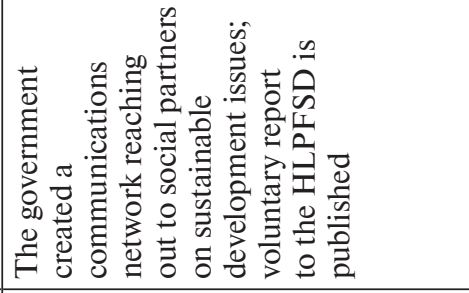 \\
\hline 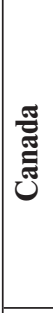 & 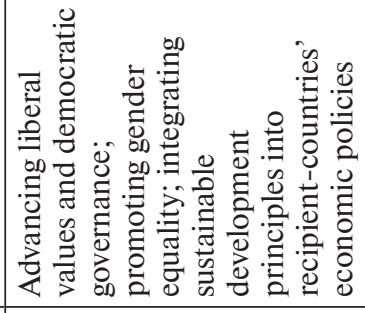 & 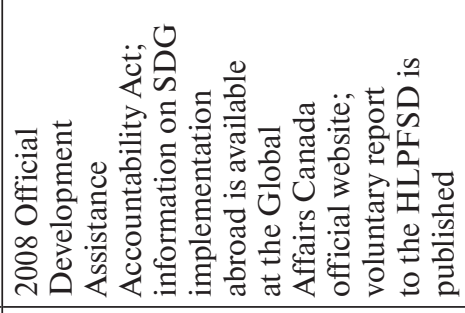 \\
\hline 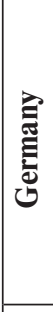 & 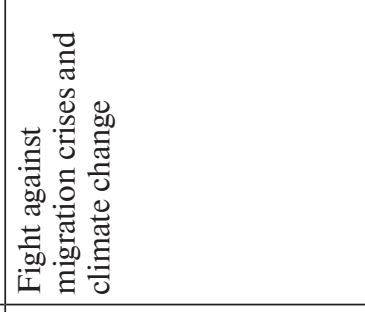 & 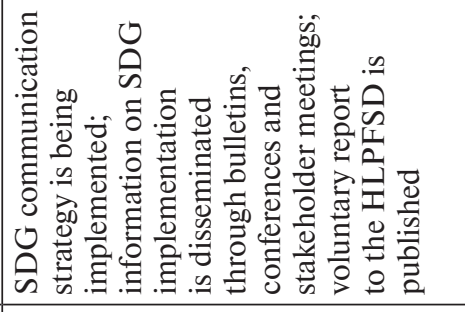 \\
\hline & 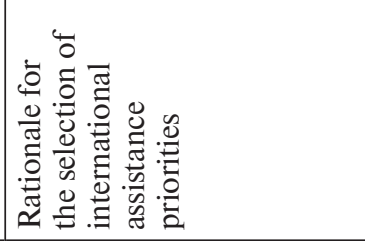 & 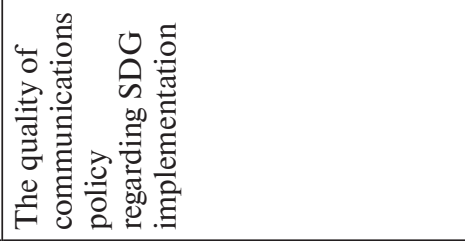 \\
\hline
\end{tabular}


The experience of developed countries shows that formalized state institutions, such as the Sustainable Development Advisory Council (Canada) or the Committee of State Secretaries for Sustainable Development (Germany), created with the aim of forming national strategies and monitoring their execution, can become a vital channel of communication with non-state actors. Currently there are no mechanisms for public participation in decision-making in the field of sustainable development in the Russian Federation.

The state policy on the implementation of the SDGs should take into account not only national, but also international objectives. In this regard, an important role is played by the integration of the SDGs and sustainable development priorities in foreign assistance strategies. Foreign aid projects also require attention to the balance of social, economic and environmental aspects of the recipient countries' development within their national economic growth strategies, integrating the issues of social and income equality that are relevant for these states, minimizing gender and age barriers for economic development and reducing the negative impact of business on the environment. To this end, it is necessary to improve the institutional structure and promote capacity building for government officials responsible for the formulation and implementation of state policy in the area of international assistance.

Finally, given the importance of the communications aspects of foreign aid activities, it is necessary to create open accountability mechanisms, enhance accessibility and upgrade the content of the existing information dissemination channels, in particular, the website of Rossotrudnichestvo, the government agency responsible for the implementation of Russia's foreign aid policy. Using these channels, it is necessary to effectively convey to citizens of Russia and recipient countries, as well as the wider global community, the value of Russian assistance efforts, and to demonstrate that this assistance is integrated into the global efforts to achieve the sustainable development goals approved by the United Nations.

\section{References}

Bundesministerium für Bildung und Forschung (2010) Nationale Forschungsstrategie BioÖkonomie 2030. Unser Weg zu einer bio-basierten Wirtschaft. Available at: https://www.bmbf.de/pub/Nationale Forschungsstrategie_Biooekonomie_2030.pdf (accessed 15 June 2018).

Cabinet of Japan (2002) Basic Programme for Persons with Disabilities. Available at: http://www8.cao. go.jp/shougai/english/basicprogram/contents.html (accessed 15 June 2018).

Cabinet of Japan (2014) Action Plan for National Resilience. Available at: https://www.cas.go.jp/jp/seisaku/kokudo_kyoujinka/en/action_plan.html (accessed 15 June 2018).

Cabinet of Japan (2014) Fundamental Plan for National Resilience. Available at: https://www.cas.go.jp/ jp/seisaku/kokudo_kyoujinka/en/fundamental_plan.html (accessed 15 June 2018).

Cabinet of Japan (2015) The $5^{\text {th }}$ Science and Technology Basic Plan. Available at: http://www8.cao.go.jp/ cstp/kihonkeikaku/5basicplan_en.pdf (accessed 15 June 2018). 
Die Bundesregierung (2014) Meilensteine der Nachhaltigkeitspolitik. Weiterentwicklung der nationalen Nachhaltigkeitsstrategie. Available at: https://www.nachhaltigkeitsrat.de/wp-content/uploads/migration/documents/2015-02-03-meilensteine-der-nachhaltigkeitspolitik.pdf_(accessed 15 June 2018).

Die Bundesregierung (2016) Deutsche Nachhaltigkeitsstrategie. Available at: https://www.bundesregierung.de/Content/DE/_Anlagen/Nachhaltigkeit-wiederhergestellt/2017-01-11-nachhaltigkeitsstrategie.pdf?_blob=publicationFile \&v=22 (accessed 15 June 2018).

Die Bundesregierung (2017) Nationales Programm für nachhaltigen Konsum. Available at: http://www. bmu.de/fileadmin/Daten_BMU/Download_PDF/Produkte_und_Umwelt/nat_programm_konsum_ bf.pdf (accessed 15 June 2018).

Division for Sustainable Development Goals, United Nations Department of Economic and Social Affairs (UN DESA) (2016) Proposal for voluntary common reporting guidelines for Voluntary National Reviews at the HLPF. Available at: https://sustainabledevelopment.un.org/content/ documents/9768Guidelines\%20from\%20SG\%20report.pdf (accessed 15 June 2018).

Division for Sustainable Development Goals, United Nations Department of Economic and Social Affairs (UN DESA) (2018) Canada's Voluntary National Review - Report Synopsis. Available at: https:// sustainabledevelopment.un.org/index.php?page $=$ view \&type $=30022 \& n r=1049 \&$ menu $=3170 \quad$ (accessed 15 June 2018).

Federal Minister for Family Affairs, Senior Citizens, Women and Youth (2015) The ElterngeldPlus with partnership bonus and more flexible parental leave. Available at: https://www.bmfsfj.de/blob/93632/05 485225123c3b6093ffaf3d36bb5568/elterngeldplus-mit-partnerschaftsbonus-englisch-data.pdf (accessed 15 June 2018).

Federal Ministry for the Environment, Nature Conservation and Nuclear Safety (2007) National Strategy on Biological Diversity. Available at: https://www.bfn.de/fileadmin/ABS/documents/Biodiversitaetsstragie_englisch.pdf (accessed 15 June 2018).

G7 Leaders (2015) Leaders' Declaration of the G7 Elmau Summit. Available at: https://sustainabledevelopment.un.org/content/documents/7320LEADERS\%20STATEMENT_FINAL_CLEAN.pdf (accessed 15 June 2018).

Gender Equality Bureau Cabinet Office (2016) The Fourth Basic Plan for Gender Equality. Available at: http://www.gender.go.jp/english_contents/pr_act/pub/pamphlet/women-and-men16/pdf/2-4.pdf (accessed 15 June 2018).

German Federal Ministry for Economic Cooperation and Development (2017) Making a Difference. Germany's Development Cooperation. Available at: https://www.bmz.de/en/publications/type_of_ publication/information_flyer/flyer/Flyer_EZ_wirkt_en.pdf (accessed 15 June 2018).

German Federal Ministry for the Environment, Nature Conservation, Building and Nuclear Safety (2016) The German Resource Efficiency Programme II. Available at: http://www.bmu.de/fileadmin/ Daten_BMU/Download_PDF/Ressourceneffizienz/the_german_resource_efficiency_programme_ summary_ii_bf.pdf (accessed 15 June 2018).

German Federal Ministry of Education and Research (2014) Green Economy Research Agenda. Available at: https://www.bmbf.de/pub/Green_Economy_Research_Agenda.pdf (accessed 15 June 2018).

German Federal Ministry of Food and Agriculture (2014) National Policy Strategy on Bioeconomy. Available at: http://www.bmel.de/SharedDocs/Downloads/EN/Publications/NatPolicyStrategyBioeconomy.pdf?_blob=publicationFile (accessed 15 June 2018).

German Government (2010) Energy Concept 2050 for Germany with a European and Global Perspective. Available at: http://www.fvee.de/fileadmin/publikationen/Politische_Papiere_FVEE/10.06.Energy_Concept_2050/EK2010_EN.pdf (accessed 15 June 2018).

German Government (2014) The new High-Tech Strategy Innovations for Germany. Available at: https://www.bmbf.de/pub/HTS_Broschuere_eng.pdf (accessed 15 June 2018).

German Government (2016) German Sustainable Development Strategy. Available at: https://www. bundesregierung.de/Content/EN/StatischeSeiten/Schwerpunkte/Nachhaltigkeit/Anlagen/2017- 
06-20-langfassung-n-en.pdf;jsessionid=06E39608902E3212B7A895E5E0D6ECBB.s3t1? blob $=$ publicationFile \&v $=5$ (accessed 15 June 2018).

German Government (2016) National Action Plan. Implementation of the UN Guiding Principles on Business and Human Rights 2016-2020. Available at: https://www.business-humanrights.org/sites/ default/files/documents/NAP\%20Business\%20Human\%20Rights_English\%281\%29.pdf (accessed 15 June 2018).

German Government (2017) National Programme on Sustainable Consumption. From Sustainable Lifestyles towards Social Change. Available at: http://www.bmu.de/fileadmin/Daten_BMU/Pools/Broschueren/nachhaltiger_konsum_broschuere_en_bf.pdf (accessed 15 June 2018).

Government of Canada (2008) Federal Sustainable Development Act. Available at: http://laws-lois.justice.gc.ca/eng/acts/F-8.6/page-1.html (accessed 15 June 2018).

Government of Canada (2016) Federal sustainable Development Strategy. Available at: https://www.canada.ca/en/services/environment/conservation/sustainability/federal-sustainable-development-strategy. html (accessed 15 June 2018).

Government of Canada (2018a) Canada's Implementation of the 2030 Agenda for Sustainable Development. Available at: https://sustainabledevelopment.un.org/content/documents/20312Canada_ENGLISH_18122_Canadas_Voluntary_National_ReviewENv7.pdf (accessed 15 June 2018).

Government of Canada (2018b) The 2030 Agenda for Sustainable Development. Available at: http://international.gc.ca/world-monde/2030-agenda_VNR-ENV_programme_2030.aspx?lang=eng (accessed 15 June 2018).

Government of Canada (c. a., a) Canada's Feminist International Assistance Policy. Available at: http:// international.gc.ca/world-monde/issues_development-enjeux_developpement/priorities-priorites/policy-politique.aspx?lang=eng (accessed 15 June 2018).

Government of Canada (c.a., b) Global Affairs Canada, Priorities. Available at: http://www.international.gc.ca/gac-amc/priorities-priorites.aspx?lang=eng (accessed 15 June 2018).

Government of Canada (c. a., c) Project browser. Available at: http://w05.international.gc.ca/projectbrowser-banqueprojets/filter-filtre (accessed 16 June 2018).

JICA (2017) JICA Annual Report. Available at: https://www.jica.go.jp/english/publications/reports/annual/2017/c8h0vm0000bws721-att/2017_all.pdf (accessed 15 June 2018).

Ministry of Commerce of the People's Republic of China (2018) Year-end Overview XXIII for Commerce Work in 2017 Pragmatically Pushing China-Africa Win-Win Trade and Economic Relations. Available at: http://english.mofcom.gov.cn/article/zt_overview2017/news/201803/20180302718786.shtml (accessed 15 June 2018).

Ministry of Foreign Affairs of Japan (2015) Cabinet decision on the Development Cooperation Charter. Available at: http://www.mofa.go.jp/files/000067701.pdf (accessed 15 June 2018).

Ministry of Foreign Affairs of Japan (2016) TICAD VI Nairobi Declaration. Available at: http://www. mofa.go.jp/af/afl/page3e_000543.html (accessed 15 June 2018).

Ministry of Foreign Affairs of Japan (2017) Japan's Development Cooperation Policy. Development Cooperation Charter. Available at: https://www.mofa.go.jp/files/000286313.pdf (accessed 15 June 2018).

Ministry of Foreign Affairs of Japan (2017) Japan's Voluntary National Review. Available at: http://www. mofa.go.jp/files/000287390.pdf (accessed 15 June 2018).

Ministry of Foreign Affairs of Japan (2017) The SDG's Implementation Guiding Principles. Available at: http://www.mofa.go.jp/files/000252819.pdf (accessed 15 June 2018).

Ministry of Foreign Affairs of Japan (2017) White Paper on Development Cooperation 2016. Japan's International Cooperation. Available at: https://www.mofa.go.jp/files/000282089.pdf (accessed 15 June 2018).

Ministry of Foreign Affairs of Japan (c. a.) Japan's Security Policy. Available at: http://www.mofa.go.jp/ $\mathrm{fp} /$ nsp/page1we_000081.html (accessed 15 June 2018). 
Ministry of Land, Infrastructure, Transport and Tourism (2016) New Tourism Strategy to Invigorate the Japanese Economy. Available at: http://www.mlit.go.jp/common/001172615.pdf (accessed 15 June 2018).

Ministry of Land, Infrastructure, Transport and Tourism (2015) National Spatial Strategy. Available at: http://www.mlit.go.jp/common/001127196.pdf (accessed 15 June 2018).

Ministry of Planning, Budget and Management (2015) Guidelines for Elaboration of Multiannual Plan 2016-2019. Available at: http://www.planejamento.gov.br/secretarias/upload/Arquivos/ppa-2016/orientacoes_elaboracao_ppa_2016_2019_02.pdf (accessed 15 June 2018).

Ministry of the Environment (2012) The National Biodiversity Strategy of Japan 2012-2020. Available at: http://www.env.go.jp/press/files/en/528.pdf (accessed 15 June 2018).

Ministry of the Environment (2014) Outline of the Basic Act on Water Cycle Policy. Available at: https:// www.env.go.jp/en/focus/docs/files/20140902-90.pdf (accessed 15 June 2018).

Nomura H. (2017) Japan's Agriculture, Forestry and Fisheries Product Export Infrastructure Improvement Program. Available at: http://ap.fftc.agnet.org/ap_db.php?id=769 (accessed 15 June 2018).

Organisation for Economic Co-operation and Development (OECD) (2016) Development Co-operation Report 2016. Available at: http://www.keepeek.com/Digital-Asset-Management/oecd/development/development-co-operation-report-2016_dcr-2016-en\#page 179 (accessed 15 June 2018).

Organisation for Economic Co-operation and Development (OECD) (c. a.) OECD Data. Available at: https://data.oecd.org/ (accessed 30 August 2018).

President of Russia (2018) The President signed Executive Order on National Goals and Strategic Objectives of the Russian Federation through to 2024. Available at: http://en.kremlin.ru/events/president/ news/57425 (accessed 15 June 2018).

Prime Minister of Japan and His Cabinet (2016) Japan Revitalization Strategy 2016. Available at: https:// www.kantei.go.jp/jp/singi/keizaisaisei/pdf/hombun1_160602_en.pdf (accessed 15 June 2018).

Prime Minister of Japan and His Cabinet (2018) The Japan's Plan for Dynamic Engagement of All Citizens. Available at: https://japan.kantei.go.jp/content/jpnplnde_en.pdf (accessed 15 June 2018).

Prime Minister of Japan and His Cabinet (c. a.) The Action Plan for Strengthening Measures on Emerging Infectious Diseases. Available at: http://www.kantei.go.jp/jp/singi/kokusai_kansen/pdf/plan_for_ infectious_outline.pdf (accessed 15 June 2018).

Secretariat of Government of the Presidency of the Republic (2017) Voluntary National Report on the Sustainable Development Goals. Available at: https://sustainabledevelopment.un.org/content/ documents/15806Brazil_English.pdf (accessed 15 June 2018).

Strategic Council for AI Technology (2017) Artificial Intelligence Technology Strategy. Available at: http://www.nedo.go.jp/content/100865202.pdf (accessed 15 June 2018).

Stuart E., Samman E. (2017) Defining "leave no one behind". Briefing Paper. London: ODI. Available at: https://www.odi.org/ sites/odi.org.uk/files/resource-documents/11809.pdf (accessed 15 June 2018).

The Federal Government (2016) Report of the German Federal Government to the High-Level Political Forum on Sustainable Development 2016. Available at: https://sustainabledevelopment.un.org/content/ documents/10686HLPF-Bericht_final_EN.pdf (accessed 16 June 2018).

The Government of Japan (2016) The National Action Plan on Antimicrobial Resistance (AMR). Available at: http://www.mhlw.go.jp/file/06-Seisakujouhou-10900000-Kenkoukyoku/0000138942.pdf (accessed 15 June 2018).

The Press and Information Office of the Federal Government (c. a.) Available at: https://www.bundesregierung.de/Content/EN/StatischeSeiten/breg/federal-press-office-overview.html?nn=393272 (accessed 15 June 2018).

United Nations (2015) Transforming our world: the 2030 Agenda for Sustainable Development. Available at: https://unctad.org/meetings/en/SessionalDocuments/ares70d1_en.pdf (accessed 15 June 2018). 


\title{
Подходы ведущих стран-доноров к внедрению ЦУР в национальные стратегии устойчивого развития
}

\author{
А.А. Игнатов, С.В. Михневич, И.М. Попова, Е.А. Сафонкина, \\ А.Г. Сахаров, А.В. Шелепов
}

Игнатов Александр Александрович - м.н.с. Центра исследований международных институтов Российской академии народного хозяйства и государственной службы при Президенте РФ; Российская Федерация, 119034, Москва, Пречистенская наб., д. 11; E-mail: ignatov-aa@ranepa.ru

Михневич Сергей Владимирович - к.полит.н., н.с. Центра исследований международных институтов РАНХиГС, директор Центра по многостороннему сотрудничеству Российского союза промышленников и предпринимателей; Российская Федерация, 119034, Москва, Пречистенская наб., д. 11; E-mail: sxzex@ yandex.ru

Попова Ирина Максимовна - м.н.с. Центра исследований международных институтов Российской академии народного хозяйства и государственной службы при Президенте РФ (РАНХиГС); Российская Федерация, 101000, Москва, ул. Мясницкая, д. 20; E-mail: impopova_1@edu.hse.ru; popova-im@ranepa.ru

Сафонкина Елизавета Андреевна - н.с. Центра исследований международных институтов (ЦИМИ) Российской академии народного хозяйства и государственной службы при Президенте РФ (РАНХиГС); Российская Федерация, 119034, Москва, Пречистенская наб., д. 11; E-mail: safonkina-ea@ranepa.ru

Сахаров Андрей Геннадиевич - н.с. Центра исследований международных институтов Российской академии народного хозяйства и государственной службы при Президенте РФ; Российская Федерация, 119034, Москва, Пречистенская наб., д. 11; E-mail: sakharov-ag@ranepa.ru_

Шелепов Андрей Владимирович - н.с. Центра исследований международных институтов Российской академии народного хозяйства и государственной службы при Президенте РФ (РАНХиГС); Российская Федерация, 119034, Москва, Пречистенская наб., д. 11; E-mail: shelepovav@ranepa.ru

Цели устойчивого развития, принятые Генеральной Ассамблеей ООН 25 сентября 2015 г., охватывают широкий спектр проблем, с которыми сталкиваются развивающиеся и развитые страны. Повестка 2030 ориентирована на борьбу с нищетой во всех ее проявлениях через реализацию стратегий устойчивого экономического роста.

Проблематика достижения ЦУР актуальна и для международной повестки дня, и для национальной политики. В настоящей статье рассматривается политика шести стран - крупных доноров международной помощи по достижению ЦУР как внутри страны, так и в рамках мероприятий в сфере СМР. Для анализа были отобраны три крупных донора из числа развитых стран: Германия, Канада и Япония, а также три новых развивающихся донора: Бразилия, Индия и Китай.

Основой сравнительного анализа стали следующие аспекты национальной политики по достижению ЦУР: а) учет задач ЦУР в рамках национальных концептуальных и стратегических документов; б) институциональная организация и учет интересов социальных партнеров; в) интеграция приоритетов ЦУР в стратегии содействия международному развитию; г) официальная мотивация оказания международной помощи; д) качество коммуникационной политики в сфере реализации ЦУР.

Анализ опыта указанных государств по локализации ЦУР позволил выработать рекомендации для начала работы в данном направлении в Российской Федерации. Рекомендации представлены в заключительном разделе статьи.

Ключевые слова: Цели устойчивого развития; устойчивое развитие; содействие международному развитию; Повестка дня в области устойчивого развития на период до 2030 г.; официальная помощь развитию

Для цитирования: Игнатов А.А., Михневич С.В., Попова И.М., Сафонкина Е.А., Сахаров А.Г., Шелепов А.В. (2019) Подходы ведущих стран-доноров к внедрению ЦУР в национальные стратегии устойчивого развития // Вестник международных организаций. Т. 14. № 1. С. 164-188 (на русском и английском языках). DOI: $10.17323 / 1996-7845-2019-01-10$ 


\section{Источники}

ООН (2015) Преобразование нашего мира: Повестка дня в области устойчивого развития на период до 2030 года. Режим доступа: https://documents-dds-ny.un.org/doc/UNDOC/GEN/N15/285/75/PDF/ N1528575.pdf?OpenElement (дата обращения: 15.06.2018).

Официальный сайт Президента РФ (2018) Президент подписал Указ «О национальных целях и стратегических задачах развития Российской Федерации на период до 2024 года». Режим доступа: http://kremlin.ru/events/president/news/57425 (дата обращения: 15.06.2018).

Правительство Германии (2016) Стратегия устойчивого развития Германии. Режим доступа: https://www.bundesregierung.de/Content/EN/StatischeSeiten/Schwerpunkte/Nachhaltigkeit/Anlagen/201711-15-kurzpapier-n-russisch.pdf;jsessionid=06E39608902E3212B7A895E5E0D6ECBB.s3t1? blob=publicationFile \&v=2 (дата обращения: 15.06.2018).

Японское агентство международного сотрудничества (с. а.) Профиль деятельности ЈICА. Режим доступа: https://www.jica.go.jp/english/publications/brochures/pdf/jicaprofile_russian_01.pdf (дата обращения: 15.06.2018).

Bundesministerium für Bildung und Forschung (2010) Nationale Forschungsstrategie BioÖkonomie 2030. Unser Weg zu einer bio-basierten Wirtschaft. Режим доступа:https://www.bmbf.de/pub/Nationale_Forschungsstrategie_Biooekonomie_2030.pdf (дата обращения: 15.06.2018).

Cabinet of Japan (2002) Basic Programme for Persons with Disabilities. Режим доступа: http://www8.cao. go.jp/shougai/english/basicprogram/contents.html (дата обращения: 15.06.2018).

Cabinet of Japan (2014) Action Plan for National Resilience. Режим доступа: https://www.cas.go.jp/jp/seisaku/kokudo_kyoujinka/en/action_plan.html (дата обращения: 15.06.2018).

Cabinet of Japan (2014) Fundamental Plan for National Resilience. Режим доступа: https://www.cas.go.jp/ jp/seisaku/kokudo_kyoujinka/en/fundamental_plan.html (дата обращения: 15.06.2018).

Cabinet of Japan (2015) The $5^{\text {th }}$ Science and Technology Basic Plan. Режим доступа: http://www8.cao.go.jp/ cstp/kihonkeikaku/5basicplan_en.pdf (дата обращения: 15.06.2018).

Die Bundesregierung (2014) Meilensteine der Nachhaltigkeitspolitik. Weiterentwicklung der nationalen Nachhaltigkeitsstrategie. Режим доступа: https://www.nachhaltigkeitsrat.de/wp-content/uploads/migration/ documents/2015-02-03-meilensteine-der-nachhaltigkeitspolitik.pdf_(дата обращения: 15.06.2018).

Die Bundesregierung (2016) Deutsche Nachhaltigkeitsstrategie. Режим доступа: https://www.bundesregierung.de/Content/DE/_Anlagen/Nachhaltigkeit-wiederhergestellt/2017-01-11-nachhaltigkeitsstrategie. pdf?__blob=publicationFile\&v=22 (дата обращения: 15.06.2018).

Die Bundesregierung (2017) Nationales Programm für nachhaltigen Konsum. Режим доступа: http://www. bmu.de/fileadmin/Daten_BMU/Download_PDF/Produkte_und_Umwelt/nat_programm_konsum_bf.pdf (дата обращения: 15.06.2018).

Division for Sustainable Development Goals, United Nations Department of Economic and Social Affairs (UN DESA) (2016) Proposal for voluntary common reporting guidelines for Voluntary National Reviews at the HLPF. Режим доступа: https://sustainabledevelopment.un.org/content/documents/9768Guidelines\%20 from\%20SG\%20report.pdf (дата обращения: 15.06.2018).

Division for Sustainable Development Goals, United Nations Department of Economic and Social Affairs (UN DESA) (2018) Canada's Voluntary National Review - Report Synopsis. Режим доступа: https://sustainabledevelopment.un.org/index.php?page=view\&type $=30022 \& n r=1049 \& m e n u=3170$ (дата обращения: 16.06.2018).

Federal Minister for Family Affairs, Senior Citizens, Women and Youth (2015) The ElterngeldPlus with partnership bonus and more flexible parental leave. Режим доступа: https://www.bmfsfj.de/blob/93632/05485 225123c3b6093ffaf3d36bb5568/elterngeldplus-mit-partnerschaftsbonus-englisch-data.pdf (дата обращения: 15.06.2018).

Federal Ministry for the Environment, Nature Conservation and Nuclear Safety (2007) National Strategy on Biological Diversity. Режим доступа: https://www.bfn.de/fileadmin/ABS/documents/Biodiversitaetsstragie_ englisch.pdf (дата обращения: 15.06.2018). 
G7 Leaders (2015) Leaders' Declaration of the G7 Elmau Summit. Режим доступа: https://sustainabledevelopment.un.org/content/documents/7320LEADERS\%20STATEMENT_FINAL_CLEAN.pdf (дата обращения: 15.06.2018).

Gender Equality Bureau Cabinet Office (2016) The Fourth Basic Plan for Gender Equality. Режим доступа: http://www.gender.go.jp/english_contents/pr_act/pub/pamphlet/women-and-men16/pdf/2-4.pdf (дата обращения: 15.06.2018).

German Federal Ministry for Economic Cooperation and Development (2017) Making a Difference. Germany's Development Cooperation. Режим доступа: https://www.bmz.de/en/publications/type_of_publication/ information_flyer/flyer/Flyer_EZ_wirkt_en.pdf (дата обращения: 15.06.2018).

German Federal Ministry for the Environment, Nature Conservation, Building and Nuclear Safety (2016) The German Resource Efficiency Programme II. Режим доступа: http://www.bmu.de/fileadmin/Daten_BMU/ Download_PDF/Ressourceneffizienz/the_german_resource_efficiency_programme_summary_ii_bf.pdf (дата обращения: 15.06.2018).

German Federal Ministry of Education and Research (2014) Green Economy Research Agenda. Режим доступа: https://www.bmbf.de/pub/Green_Economy_Research_Agenda.pdf (дата обращения: 15.06.2018).

German Federal Ministry of Food and Agriculture (2014) National Policy Strategy on Bioeconomy. Режим доступа: http://www.bmel.de/SharedDocs/Downloads/EN/Publications/NatPolicyStrategyBioeconomy. pdf?_blob=publicationFile (дата обращения: 15.06.2018).

German Government (2010) Energy Concept 2050 for Germany with a European and Global Perspective. Режим доступа: http://www.fvee.de/fileadmin/publikationen/Politische_Papiere_FVEE/10.06.Energy_ Concept_2050/EK2010_EN.pdf (дата обращения: 15.06.2018).

German Government (2014) The new High-Tech Strategy Innovations for Germany. Режим доступа: https:// www.bmbf.de/pub/HTS_Broschuere_eng.pdf (дата обращения: 15.06.2018).

German Government (2016) German Sustainable Development Strategy. Режим доступа: https://www. bundesregierung.de/Content/EN/StatischeSeiten/Schwerpunkte/Nachhaltigkeit/Anlagen/2017-06-20-langfassung-n-en.pdf;jsessionid=06E39608902E3212B7A895E5E0D6ECBB.s3t1?_blob=publicationFile \&v=5 (дата обращения: 15.06.2018).

German Government (2016) National Action Plan. Implementation of the UN Guiding Principles on Business and Human Rights 2016-2020. Режим доступа: https://www.business-humanrights.org/sites/default/files/ documents/NAP\%20Business\%20Human\%20Rights_English\%281\%29.pdf (дата обращения: 15.06.2018).

German Government (2017) National Programme on Sustainable Consumption. From Sustainable Lifestyles towards Social Change. Режим доступа: http://www.bmu.de/fileadmin/Daten_BMU/Pools/Broschueren/ nachhaltiger_konsum_broschuere_en_bf.pdf (дата обращения: 15.06.2018).

Government of Canada (c. a., a) Canada's Feminist International Assistance Policy. Режим доступа: http:// international.gc.ca/world-monde/issues_development-enjeux_developpement/priorities-priorites/policypolitique.aspx?lang=eng.(дата обращения: 15.06.2018).

Government of Canada (c. a., b) Global Affairs Canada, Priorities. Режим доступа: http://www.international. gc.ca/gac-amc/priorities-priorites.aspx?lang=eng (дата обращения: 15.06.2018).

Government of Canada (c. а., c) Project browser. Режим доступа: http://w05.international.gc.ca/projectbrowser-banqueprojets/filter-filtre (дата обращения: 16.06.2018).

Government of Canada (2008) Federal Sustainable Development Act. Режим доступа: http://laws-lois.justice.gc.ca/eng/acts/F-8.6/page-1.html (дата обращения: 15.06.2018).

Government of Canada (2016) Federal sustainable Development Strategy. Режим доступа: https://www.canada.ca/en/services/environment/conservation/sustainability/federal-sustainable-development-strategy.html (дата обращения: 15.06.2018).

Government of Canada (2018a) Canada's Implementation of the 2030 Agenda for Sustainable Development. Режим доступа: https://sustainabledevelopment.un.org/content/documents/20312Canada_ENGLISH_18122_Canadas_Voluntary_National_ReviewENv7.pdf (дата обращения: 16.06.2018).

Government of Canada (2018b) the 2030 Agenda for Sustainable Development. Режим доступа: http://international.gc.ca/world-monde/2030-agenda_VNR-ENV_programme_2030.aspx?lang=eng (дата обращения: 16.06.2018). 
JICA (2017) JICA Annual Report. Режим доступа: https://www.jica.go.jp/english/publications/reports/annual/2017/c8h0vm0000bws721-att/2017_all.pdf (дата обращения: 15.06.2018).

Ministry of Commerce of the People's Republic of China (2018) Year-end Overview XXIII for Commerce Work in 2017: Pragmatically Pushing China-Africa Win-Win Trade and Economic Relations. Pежим доступа: http://english.mofcom.gov.cn/article/zt_overview2017/news/201803/20180302718786.shtml (дата обращения: 15.03.2018).

Ministry of Foreign Affairs of Japan (2015) Cabinet decision on the Development Cooperation Charter. Pежим доступа: http://www.mofa.go.jp/files/000067701.pdf (дата обращения: 15.06.2018).

Ministry of Foreign Affairs of Japan (2016) TICAD VI Nairobi Declaration. Режим доступа: http://www. mofa.go.jp/af/afl/page3e_000543.html (дата обращения: 15.06.2018).

Ministry of Foreign Affairs of Japan (2017) Japan's Development Cooperation Policy. Development Cooperation Charter. Режим доступа: https://www.mofa.go.jp/files/000286313.pdf (дата обращения: 15.06.2018).

Ministry of Foreign Affairs of Japan (2017) Japan’s Voluntary National Review. Режим доступа: http://www. mofa.go.jp/files/000287390.pdf (дата обращения: 15.06.2018).

Ministry of Foreign Affairs of Japan (2017) The SDG's Implementation Guiding Principles. Режим доступа: http://www.mofa.go.jp/files/000252819.pdf (дата обращения: 15.06.2018).

Ministry of Foreign Affairs of Japan (2017) White Paper on Development Cooperation 2016. Japan's International Cooperation. Режим доступа: https://www.mofa.go.jp/files/000282089.pdf (дата обращения: 15.06.2018).

Ministry of Foreign Affairs of Japan (c. а.) Japan’s Security Policy. Режим доступа: http://www.mofa.go.jp/ fp/nsp/page1we_000081.html (дата обращения: 15.06.2018).

Ministry of Land, Infrastructure, Transport and Tourism (2016) New Tourism Strategy to Invigorate the Japanese Economy. Режим доступа: http://www.mlit.go.jp/common/001172615.pdf (дата обращения: 15.06.2018).

Ministry of Land, Infrastructure, Transport and Tourism (2015) National Spatial Strategy. Режим доступа: http://www.mlit.go.jp/common/001127196.pdf (дата обращения: 15.06.2018).

Ministry of Planning, Budget and Management (2015) Guidelines for Elaboration of Multiannual Plan 20162019. Режим доступа: http://www.planejamento.gov.br/secretarias/upload/Arquivos/ppa-2016/orientacoes elaboracao_ppa_2016_2019_02.pdf (дата обращения: 15.06.2018).

Ministry of the Environment (2012) The National Biodiversity Strategy of Japan 2012-2020. Режим доступа: http://www.env.go.jp/press/files/en/528.pdf (дата обращения: 15.06.2018).

Ministry of the Environment (2014) Outline of the Basic Act on Water Cycle Policy. Режим доступа: https:// www.env.go.jp/en/focus/docs/files/20140902-90.pdf (дата обращения: 15.06.2018).

Nomura H. (2017) Japan's Agriculture, Forestry and Fisheries Product Export Infrastructure Improvement Program. Режим доступа: http://ap.fftc.agnet.org/ap_db.php?id=769 (дата обращения: 15.06.2018).

Organisation for Economic Co-operation and Development (OECD) (2016) Development Co-operation Report 2016. Режим доступа: http://www.keepeek.com/Digital-Asset-Management/oecd/development/development-co-operation-report-2016_dcr-2016-en\#page179 (дата обращения: 15.06.2018).

Organisation for Economic Co-operation and Development (OECD) (c. а.) OECD Data. Режим доступа: https://data.oecd.org/ (дата обращения: 15.06.2018).

Prime Minister of Japan and His Cabinet (2016) Japan Revitalization Strategy 2016. Режим доступа: https:// www.kantei.go.jp/jp/singi/keizaisaisei/pdf/hombun1_160602_en.pdf (дата обращения: 15.06.2018).

Prime Minister of Japan and His Cabinet (2018) The Japan's Plan for Dynamic Engagement of All Citizens. Режим доступа: https://japan.kantei.go.jp/content/jpnplnde_en.pdf (дата обращения: 15.06.2018).

Prime Minister of Japan and His Cabinet (c. a.) The Action Plan for Strengthening Measures on Emerging Infectious Diseases. Режим доступа: http://www.kantei.go.jp/jp/singi/kokusai_kansen/pdf/plan_for_infectious_outline.pdf (дата обращения: 15.06.2018).

Secretariat of Government of the Presidency of the Republic (2017) Voluntary National Report on the Sustainable Development Goals. Режим доступа: https://sustainabledevelopment.un.org/content/ documents/15806Brazil_English.pdf (дата обращения: 15.06.2018). 
Strategic Council for AI Technology (2017) Artificial Intelligence Technology Strategy. Режим доступа: http://www.nedo.go.jp/content/100865202.pdf (дата обращения: 15.06.2018).

Stuart E., Samman E. (2017) Defining "leave no one behind”. Briefing Paper. London: ODI. Режим доступа: https://www.odi.org/ sites/odi.org.uk/files/resource-documents/11809.pdf (дата обращения: 15.06.2018).

The Federal Government (2016) Report of the German Federal Government to the High-Level Political Forum on Sustainable Development 2016. Режим доступа: https://sustainabledevelopment.un.org/content/ documents/10686HLPF-Bericht_final_EN.pdf (дата обращения: 16.06.2018).

The Government of Japan (2016) The National Action Plan on Antimicrobial Resistance (AMR). Режим доступа: http://www.mhlw.go.jp/file/06-Seisakujouhou-10900000-Kenkoukyoku/0000138942.pdf (дата обращения: 15.06.2018).

The Press and Information Office of the Federal Government (с. а.) Режим доступа: https://www.bundesregierung.de/Content/EN/StatischeSeiten/breg/federal-press-office-overview.html?nn=393272 （дата обращения: 16.06.2018). 